\title{
Planning for smart sustainable cities
}

\author{
Decisions in the planning process and actor networks
}

\author{
Anna Kramers, Josefin Wangel, Mattias Höjer \\ Centre for Sustainable Communications CESC \\ and \\ Division of Environmental Strategies Research fms \\ KTH Royal Institute of Technology \\ Stockholm, Sweden \\ kramers@kth.se,wangel@kth.se,hojer@kth.se
}

\begin{abstract}
Information and Communication Technologies (ICT) have been ascribed an important role for decreasing energy use and mitigating greenhouse gas (GHG) emissions in urban areas. Through automation, dematerialisation, persuasion and soft transformation ICT holds the potential of making urban life more sustainable, without cutting back in quality of life. To fully utilise the potential of ICT for sustainable cities there is a need to reconsider the design and technical specification of buildings and infrastructure systems, as well as what actors to involve in the planning and management of the city. A ubiquitous introduction of ICT for sustainability may also influence the spatial and institutional organisation of the city. In spite of this, there is little research on ICT for sustainable cities from the perspective of planning and governance. This paper aims to abate parts of this knowledge gap through exploring two aspects of planning that we see as crucial for a successful implementation of ICT for sustainable cities. The first of these aspects concerns when in the planning process decisions regarding ICT need to be taken. The second aspect deals with what actor networks are needed to implement the ICT solutions and how these can be managed, or meta-governed. These aspects are explored through literature studies, workshops and interviews with urban planners and other actors engaged in the Royal Seaport project in Stockholm, Sweden.
\end{abstract}

Index Terms - smart sustainable cities, planning process, actors

\section{Introduction}

Information and Communication Technologies (ICT) have been ascribed an important role for decreasing energy use and mitigating greenhouse gas (GHG) emissions in urban areas [1]. Through automation, de-materialisation, persuasion and soft transformation, ICT hold the potential of making urban life more sustainable, [2] without cutting back in quality of life.

To realise this potential however, ICT must be integrated in all stages of the life-spans of buildings and infrastructure, it must be both put in place, managed and used in ways that contribute to the decrease of energy use and GHG emissions.
This paper focuses on the first of these stages, through exploring potentials and pitfalls for urban planning to realise the potential of ICT for sustainable cities.

While the relation between ICT and urban planning has been explored to some extent in previous research, most of this has focused on how ICT can transform and improve the planning practice per se; e.g. through making it more transparent and inclusive, supporting communication and interaction across and within public authorities and citizen communities, for ballots, and for visualising proposals and results. See e.g. [3-6].

There are also a number of studies acknowledging the need for changes in competence and/or the organisation of planning and governance, as well as studies on how ICT can affect the spatial organisation of cities and regions. Most of these studies are however typically delimited to rather general claims, and lacking in support from empirical studies; Houghton et al. [4] being a noteworthy exception.

Given the large and increasing interest in ICT for sustainable cities it is surprising that so little attention has been given to the prerequisites of urban planning to proactively plan for and implement ICT solutions.

The aim of this paper is to present the research design and the theoretical framework of our project "ICT for sustainable Cities" (ICIT), as well as to report on some preliminary and early findings.

The ICIT project aims at abating at least parts of the knowledge gap mentioned. It does so through looking into two aspects of fundamental importance for urban planning to plan for and implement ICT solutions supporting environmental and energy targets:

- the timing and sequence of decisions and events in the planning process that influence the possibility to implement ICT solutions

- the actor networks needed to implement the ICT solutions and how these can be managed, or metagoverned

In the project, the case of the Stockholm Royal Seaport (SRS), Sweden is used to concretise and exemplify how ICT 
solutions are connected to physical planning. The reason for selecting the SRS is that it is an area presently being planned and constructed, with ambitious environmental targets and a high interest in ICT solutions.

\section{Planning in Sweden}

Compared to most other countries, Swedish municipalities hold a very strong position with respect to urban planning through their monopoly on spatial planning.

The planning process is conducted by the City administration in its role as an authority, steered and enforced through the various planning instruments provided by the Swedish Planning and Building Act [7]:

- The comprehensive plan is an advisory guideline for the long-term development of the geographical area.

- $\quad$ The detailed development plan is a legally binding agreement that regulates development projects. The detailed development plan is required for all developments within or adjacent to urban areas.

- $\quad$ The area regulation is not legally binding and is used for areas with no detailed development plan where the municipality wants to secure adherence to the comprehensive plan.

- A building permit is needed when constructing a new building or changing the use of a building or its external features.

The planning process used by the City of Stockholm is a combination of two processes: the planning process and the exploitation process. The reason to combine the two processes is to have one interface towards external organisations such as developers. In order to understand the possibilities for the City to engage in ICT investments it is however fruitful to look at these two processes separately.

In the exploitation process, the City acts as landowner and issues land permits. As a part of those, they can formulate demands regarding e.g. environmental performance that must be fulfilled by developers who want to exploit the area. In SRS the environmental objectives have been gathered in a document known as the action-plan [8], which is legally binding through the land-permit.

The formal regulation of the planning process points out a number of mandatory events or sub-processes, as well as in what sequence these need to take place. Even though the municipalities have a planning monopoly they are still dependent on other actors (developers etc.) to make the plans come true. This means that planning can be understood as being carried out through network governance.

\section{Planning with ICT in mind}

To proactively plan for and implement ICT solutions there are at least two aspects that need to be considered: decisions in the planning process and actor networks.

In a series of workshops, representatives from city planning departments, telecom industry and academia participated. The task during the workshop was to identify 1) when in the planning process are decisions related to ICT made 2) what decisions need to be taken when and by whom to capture the various ICT solutions' potential and 3) are there ICT solutions that affect the physical infrastructure that leads to new demands on the physical infrastructure? During the workshops, SRS was used as a case, functioning as a way to concretise the planning process. Further input was gained from studying different planning documents; used and produced by the city administrations. To identify when decisions should be made, the planning process used by the City of Stockholm was analysed. An investigation is made of the objectives in the SRS action plan to identify physical services that can be affected or substituted by ICT solutions and thereby reduce the energy usage. Suggestions are made on how ICT or ICT enabled solutions could bridge the gap of the lack of physical services to the citizens and at the same time decrease energy use. Kramers et al. [9] have identified ICT hotspots, with opportunities to support reductions of energy use. ICT hotspots means opportunities for reduced energy use for the household functions with the largest demand for energy defined by Höjer, Gullberg [10]. These ICT hotspots were mapped with physical impacts and the operational targets in the action plan (Table 1).

Actor networks concern the actors needed to implement the ICT solutions, how these cooperate and how they can be managed, or meta-governed. Since ICT solutions do not happen by themselves the smart city also needs to include an interconnected social layer of actors and institutions [7] where e.g. grid owners, architects, public transport providers, housing associations, water companies, and energy cooperatives plan for, implement and manage the ICT in their grids, urban designs, transport systems, apartments, pipes and solar panels.

For all these objects and actors to come together as one digital nervous system there is a need for coordination and translation between technologies, protocols, business models and actors. A coordinating body is also needed for seeing to that public ICT investments do not lead to unfair distribution of benefits and costs, for prioritising between different ICT investments, and for evaluating the outcome of these as regards social and ecological sustainability. It is not until looking at the larger scale available to a coordinating body that emergent effects can be identified, such as whether investments are benefiting all parts of the population or not, and if the investments have made the city not only smarter but also more sustainable. With this in mind it is clear that ICT put new issues on the planning agenda (e.g. interconnection of infra systems) that might demand other competences and other forms of organisation than is the standard today [5].

\section{IV.Planning, timing and sequence of events}

The environmental objectives in the action plan are embodied in the requirements for each stage in the planning process of the SRS district. The targets are focused around climate, ecological, social and economic sustainability. In this study the focus is on climate and ecological sustainability with the main focus on energy use. Certain physical impacts are already included in the action plan such as "reduced land use for parking spaces" and "visualisations of energy use in apartments" whereas others, such as "premises for work and education integrated in the area" and "location of buildings that 
could share energy" are not. Some of the objectives in the action plan also require that ICT solutions should be used to achieve the objectives. These requirements are both on the ICT infrastructure and solutions.

As mentioned in Section II, there are not that many legally binding documents in the planning process. It seems like the process of getting to the actual decisions is more important than the decision point. Therefore, we have investigated the role of actor networks in order to empower different stakeholders, see Section V.

However, if decisions are not taken during the planning process it might result in a less successful implementation, or a situation of 'chances lost' where the opportunity becomes 'impossible' (too expensive or technologically complicated) to implement. The planning process addresses the timing and sequence of decisions and events that are legally binding, which influence the possibility to take advantage of ICT solutions with opportunities to reduce energy use. To maximise the outcome of potential energy reductions it is necessary to identify what physical impacts enabled by ICT solutions should planned for early in the process. The ICT solution that is the enabler of the physical transformation must also be planned for so that the service is available when the new city district is in operation.

In the SRS, the City's role as property owner has facilitated the setting of more comprehensive and ambitious environmental targets than what is possible in the role as an authority. Through the land permit in the exploitation process it is possible to set additional requirements on contractors not stipulated in the Planning and Building Act. Requirements on the physical environment are primarily set on the development phase i.e. the design of the built infrastructure and not on the management of the city district after the development phase. An example of a requirement after the development phase, in the operational phase, is the requirement on energy use per square meters in buildings. By introducing new requirements on ICT and ICT enabled services that are going to be used during the entire lifecycle of the new district there are questions that needs to be solved in the planning phase. For example how can a long-term business model look like, who should be responsible for that the service exist over many years and are upgraded to new requirements? While the city decides upon rules and regulations for the construction companies to build they have limited agency over the ICT companies.

There are also issues, which are not directly controlled by the municipality, such as what household appliances a household use and thereby how much energy they use, what means of transportation they chose to use or where do they chose to work.

The targets in the program for environmental and sustainable city development in SRS, the action plan [8] has an impact of the design of the physical environment in the district.

A mapping of the objectives in the action plan for SRS is connected to physical impacts and ICT solutions and presented in Table I. How well the implementation of the ICT opportunities are done in SRS is not yet investigated.

\section{V.Actor networks}

A. Network governance

It has been argued that the way in which Western societies are being steered today reflects a fragmentation and transfer of power and responsibility from governments and public bodies of the representative democracy to private interests, NGOs and layman [11]. Indeed, that governance is enacted through networks and not by well delimited organisational bodies has been recognised at least since the 1970s (see e.g. [12] p. 19). The concept network governance, or the understanding of governance as something other than traditional governing, builds on the recognition that there has been a substantial enforcement of the networked character of governance. This shift is proposed to result from a number of mutually reinforcing processes, i.e. the global financial decline, a breaking of state autonomy, the rise of neo-liberalism and its New Strategic Management, but also from the participative turn in policy and planning $[11,13,14]$.

The more networked type of governance involve a number of potential benefits such as increased legitimacy, the creation of social capital, citizen empowerment and stakeholder buy-in (see e.g.[15]), but are also questioned in the way these modes of governance influence democratic concerns such as accountability, representation and transparency [15-17]. Within the concept of network governance there is however room for a variety of different models of governance, which can be characterised by e.g. the degree of public control and formalisation, whether they are elitist or pluralist, open or closed, and depending on when in the process participation takes place [14, 17-22].

Nyseth [17] defines network governance as "relatively stable, horizontal articulations of interdependent but operationally autonomous actors, who interact through negotiations which take place within a regulative, normative, cognitive framework that is self-regulated within limits set by external agencies and which contributes to the production of public purpose." ([17] p. 499).

When it comes to implementing ICT solutions for urban sustainability, the stability that Nyseth puts forth is however less evident but is rather one of the key problems that needs to be resolved.

\section{B. Coordination through meta-governance}

From the perspective of governing sustainable urban development it has been argued that this needs to be approached through the lens of meta-governance, in which the planning authority takes the role as meta-governor of the governance networks. This recognition is based on a number of arguments, here presented in an un-weighted order:

- Firstly, the assumption that local governance will continue to be at least partly subsumed to formal hierarchies and plans $[22,23]$.

- Secondly, there is a need for managing complexity and coordinate activities when aiming for overarching goals such as sustainable urban development [24].

- Thirdly, the metagovernor can be seen as having an important role as spokesperson for what could be 
considered as voiceless stakeholders; nature, cultural heritage or the future generations to come.

- Fourthly, it has been shown that without connections to formal institutions, it is hard for governance networks to make a change $[17,25]$. The planning authority as metagovernor provides such a connection.

- Fifthly, urban planners have also been ascribed the role as "advocates for the sustainable city; (...) [telling] persuasive stories about how sustainable places can and should be created" [26].

- Sixthly, from a network theoretical perspective, the metagovernor could also serve a role as a strategic network manager for increased network functionality, e.g. as a mediator of information [27-29]. Metagovernance is typically described as a way of indirect steering, a 'regulation of the self-regulation' [15, 22]. In an overview of planners' roles, Briasoulis [30] divides planner types into technician-planners, politician-planners and hybrid-planners. As the other two, the hybrid planner category comprises a number of more specified roles but is characterised by:

"The common belief...that the planner's technical skills are needed but must combine with other, especially communication, skills to meet specific objectives. Essential integration of the economy-society-environment interactions cannot be simply a technical exercise but is a politically and socio-culturally informed task." ([30] p. 895)

Furthermore, Briassoulis concludes that where in the continuum between "technical competence and political activism" the hybrid planner should be, will always be dependent on the situation at hand and its context ([30] p. 895). It is not hard to see the planner cum metagovernor as being more or less an equivalent to the hybrid planner.

Sehested [22] distinguishes between four types of metagovernance:

Network framing sets the overarching frame and context for the network in terms of political goals and visions, financial incentives and organisational structures. These can be given, as coming from politicians, or created, as through the building of "common discourses and narratives in the governance situation" ([22] p.248). For sustainable urban development the frame could be e.g. a sustainability program. However, depending on from which perspective sustainability is approached, different problems and solutions will be made visible and given priority. This is partly due to the inherent discursive power of the different perspectives on the issue at stake but also dependent on which actor takes side for which perspective $[25,31]$. Besides from the discursive differences, the actors' more direct power also differs in terms of resources, and the potential scope of influence. By a careful network framing the traditionally discursively weak ecological sustainability could be empowered.

Network design includes meta-governance techniques aimed at influencing which stakeholders participate in the governance network, and how interaction takes place. In this way the meta-governor can make sure that marginalised or easily overlooked groups of society are included in the governance process.

Network management comprises 'hands-on support and facilitation'. While the former two meta-governance techniques can be said to work proactively to make the governance network function smoothly, network management techniques are aimed at dealing with those tensions, conflicts and inequities that could not be avoided, or that emerge during the working time of the network.

Network participation is when the metagovernor takes an active part in the governance network, in this way influencing discussions and decisions directly. However, since this calls for the metagovernor putting aside any authoritative or steering role, it can be discussed if this is to be considered a metagovernance technique or not.

There is clearly numerous ways for the planning authority as meta-governor to influence a governance network. However, it has been shown that only framing and participation are being used to any extent, while there is an untapped potential in the other two [22]. Social network theory could be used to shed further light on why also network design and management are essential when aiming at a well-functioning governance network, visualised as drawing on Nyseth's description of " $a$ skilled planning team that was highly multi-disciplinary, as well as being autonomous, self-organized and interdependent. The result was leadership by a highly competent network, capable of constructing alternative perspectives and visions on city planning". [17].

\section{Concluding discussion}

This paper is reporting from a very early phase of the ICITproject. It is a first attempt to connect spatial planning processes with the alleged great opportunities coming from ICT, in the quest for reaching primarily environmental and energy targets, and finally sustainable cities.

At this point, we have identified two parts. First, we have tried to investigate how ICT decisions can be assigned to specific points in the planning process. At this point, this has not been very successful. It is interesting to see how difficult it is to actually connect the two different lifecycles of the built environment and of ICT solutions. They have different logics, despite the fact that there should be connections.

Taking into account the overwhelming effect that ICT has on peoples' everyday life, it is not a farfetched idea to try to see how ICT-development also could affect the spatial planning of these same everyday lives. However, this is very difficult, and probably there are many reasons for this. One is that the temporal scales are so different. ICT-development is typically a lot faster, and it is hard to imagine the lives that will be led in the buildings now being produced. However, when adding an environmental and energy perspective to this, exploring ideas of e.g. how environmental targets could be reached, gets important to at least think of. Are there possibilities to have much higher telework than commuting in future as a way to reach climate targets? In that case - what are the implications for planning new city districts? Does it mean that new kinds of spaces and buildings and transport infrastructure are needed? 
When in the planning process could this be included? Similar questions can be asked for other developments that could be beneficial or even needed for reaching ambitions environmental targets. Could the demand for large housing spaces be counter-acted somehow, and thereby reduce the amount of space needed for heating and cooling? Maybe spare rooms can be made redundant if ICT can provide easy access to space when needed - a bit like car sharing or car clubs, but instead space sharing. This could also have vast implications for spatial planning. Examples could continue discussing space for shopping, infrastructure demand etc.

The complex actor networks involved in planning and city development as well as in the development of new services have been discussed above. The discussion adds further to the complexity of these networks since it includes very uncertain development processes. Steering towards targets by counting on changes in daily life is a highly risky project. From a political perspective it can mean loosing voters and from the perspective of making bad investments it can be costly. Meanwhile, at least the discussions are needed, so that better decision support can be provided when planning for ambitious energy and environmental targets. It is likely that the results of these discussions can be much more fruitful, if they are preceded by a thorough analysis of both current and future actor networks.

Finally, in this paper we have not yet started to analyse what the role of the city administration and other public agencies could be in the future. But one line of thought is that if planning takes the turn towards counting on an exchange of physical services (such as heated floor area or transport) for ICT services, the actual existence of the ICT-services becomes crucial. A parallel could be to say that if a house is built somewhere, a road is typically also needed. Public agencies may not be the best providers of theses services, but a new role for them could be to see to that the services are implemented, and to take action if that does not happen.

\section{VII.Acknowledgment}

We gratefully acknowledge the support for the ICIT project from Vinnova and the partners to the Centre for Sustainable Communications, CESC.

\section{VIII.References}

[1] EC, Smart Cities And Communities - European Innovation Partnership in Communication from the Commission 2012 Brussels.

[2] UN-Habitat, State of the world's cities 2012/2013, Prosperities of Cities, 2013, UN-Habitat: USA and Canada.

[3] Dodgson, M. and D. Gann, Technological Innovation and Complex Systems in Cities. . Journal of Urban Technology 2011. 18(3): p. 99-111.

[4] Houghton, K., E. Miller, and M. Foth, Integrating ICT into the planning process: impacts, opportunities and challenges. . Australian Planner, , 2014. 51(1): p. 2433.
[5] Batty, M., et al., Smart cities of the future. Eur. Phys. J.special Topics, 2012. 214: p. 481-518.

[6] Fernandez-Maldonado, A.M., ICT and Spatial Planning in European Cities: Reviewing the New Charter of Athens. . Built Environment . 2012 38(4): p. 469-483.

[7] Hedström R. T. and Lundström M.J., Swedish Landuse Planning Legislation, in Planning and sustaianble urban development in Sweden, Lundström M.J., Fredriksson C., and J. Witzell, Editors. 2013, Swedish Society for Town \& Country Planning: Stockholm.

[8] City of Stockholm, Övergripande program för miljö och hållbar stadsutveckling i Norra Djurgårdsstaden (Stockholm Royal Seaport) 2010.

[9] Kramers, A., et al., Smart sustainable cities Exploring ICT solutions for reduced energy use in cities. Environmental Modelling \& Software, 2014.

[10] Höjer, M., A. Gullberg, and R. Pettersson, Images of the future City. Time and space for sustainable development2011, Dordrecht: Springer.

[11] Bogason P, Public Policy and Local Governance: Institutions in Postmodern Society. 2000, , Cheltenham: Edward Elgar Publishing Limited. .

\section{[12] Wittrock}

[13] Bucchi M, N.F., Science and Public Participation, . The Handbook of Science and Technology Studies. Third Edition., ed. O.A. Eds E J Hackett, M Lynchman, J., Wajcman, J.2008, , Cambridge, Massachusetts.: The MIT Press, .

[14] Cass N, "Participatory-Deliberative Engagement: a literature review, , 2006, , published by the School of Environment and Development", Manchester University, : Manchester M13 9PL, UK.

[15] Sørensen, E., Metagovernance: The changing role of politicians in processes of democratic governance. The American Review of Public Administration 2006 36(1): p. 98-114.

[16] Bogason P and Musso J A, "The Democratic Prospects of Network Governance" The American Review of Public Administration 2006. 36( 3): p. 318.

[17] Nyseth, T., Network Governance in Contested Urban Landscapes. Planning Theory \& Practice, 2008. 9(4): p. 497-514.

[18] Arnstein, S.R., A ladder of citizen participation. Journal of the American Institute of Planners, , 1969 35 (4): 216-224.(4): p. 216-224.

[19] Hajer, M.A. and H. Wagenaar, Deliberative Policy Analysis: Understanding Governance in the Network Society. 2003, Cambridge: Cambridge University Press.

[20] Reed, M.S., et al., "Who's in and why? A typology of stakeholder analysis methods for natural resource management" Journal of Environmental Management 200990 p. 5.

[21] Treib, O., H. Bähr, and G. Falkner, Modes of Governance: A Note Towards Conceptual 
Clarification" in (EUROGOV) No. N-05-022005, European Governance Papers

[22] Sehested, K., Urban Planners as Network Managers and Metagovenors. Planning Theory \& Practice 2009. 10(2): p. 245-263.

[23] Lundqvist , L.J., Implementation from Above: The Ecology of Power in Sweden's Environmental Governance's Governance: . An International Journal of Policy and Administration 2001. 14(3): p. 319-337.

[24] Connelly, S. and T. Richardson, Effective policy making in the uplands: Some conclusions from a case study in the Peak District National Park Drivers of Change in Upland Environments, ed. A Bonn, et al.2008, London Routledge

[25] Lundqvist, L.J., "'Greening the People"s Home": The Formative Power of Sustainable Development Discourse in Swedish Housing”. Urban Studies 2004. 41(7): p. 1283-1301.

[26] Throgmorton, J.A., Planning as Persuasive Storytelling in a Global-Scale Web of Relationships. Planning Theory \& Practice, 2003. 2 p. 125-151.

[27] Borgotti, S., et al., Reviews: Network Analysis in Social Sciences. Science 323 2009: p. 892-895

[28] Ernstson, H., et al., "Scale-crossing brokers and network governance of urban ecosystem services: The case of Stockholm" Ecology and Society 2010. 15 (4).

[29] Toikka, A., Exploring the composition of communication networks of governance - a case study on local environmental policy in Helsinki, Finland. Environmental Policy and Governance 2010. 20 (2): p. 135-145.

[30] Briassoulis, H., Who plans whose sustainability? Alternative roles for planners. Journal of Environmental Planning and Management, 1999 42(6): p. 889-902.

[31] Dovlén, S., "Professional Perspectives in Planning for Sustainability - Power Relations and Interactional Patterns". , in International Conference for Integrating Urban Knowledge \& Practice, 2005: Göteborg, Sweden, 2005. 
TABLE I. ICT or ICT-enabled solution connection to physical impacts of operational targets for Stockholm Royal Seaport [8]. Translation of targets made by authors. Numbers refer to original numbering of targets.

\begin{tabular}{|c|c|c|c|}
\hline Area/Sector & Operational Targets & $\begin{array}{l}\text { Physical impact and } \\
\text { investment needed }\end{array}$ & $\begin{array}{l}\text { ICT or ICT enabled } \\
\text { solution }\end{array}$ \\
\hline Energy & $\begin{array}{l}\text { Regular measurement \& visualisation of } \\
\text { energy use/climate impact. }(6.2 .5)\end{array}$ & $\begin{array}{l}\text { Distribution of sensors for measuring energy use; } \\
\text { Places and technology for visualisation in buildings, } \\
\text { households, enterprises, transport and infrastructure. }\end{array}$ & $\begin{array}{l}\text { Advanced metering } \\
\text { for energy; Different } \\
\text { devices for } \\
\text { visualisation }\end{array}$ \\
\hline Energy & $\begin{array}{l}\text { Individual properties shall generate its own } \\
\text { electricity based on renewable energy and } \\
\text { deliver the surplus to the smart grid. (6.2.7) }\end{array}$ & $\begin{array}{l}\text { Location of buildings; Design of buildings; } \\
\text { Equipment of buildings with local renewable energy } \\
\text { production facilities;. }\end{array}$ & $\begin{array}{l}\text { Micro-grid; Smart } \\
\text { meters }\end{array}$ \\
\hline Waste & $\begin{array}{l}\text { Regular measuring and visualisation of } \\
\text { generated waste (7.2.9) }\end{array}$ & $\begin{array}{l}\text { Distribution of sensors for measuring waste use; } \\
\text { Places and technology for visualisation in buildings, } \\
\text { households, enterprises, transport and infrastructure. }\end{array}$ & $\begin{array}{l}\text { Advanced metering } \\
\text { of waste }\end{array}$ \\
\hline Transport & $\begin{array}{l}\text { Residents/workers should walk, cycle or use } \\
\text { public transport to school/home/work. } \\
(9.2 .1)\end{array}$ & $\begin{array}{l}\text { Pedestrian and bike paths; Public transport stops and } \\
\text { stations; Premises for work and education integrated } \\
\text { in the area. }\end{array}$ & $\begin{array}{l}\text { Traveler information } \\
\text { system; Flexible } \\
\text { working place }\end{array}$ \\
\hline Transport & $\begin{array}{l}\text { Vehicular traffic is restricted and transit } \\
\text { traffic is minimised. Priority } \\
\text { should be given to walk, bicycling, and PT. } \\
(9.2 .2)\end{array}$ & $\begin{array}{l}\text { Streets designed for restriction of vehicular traffic } \\
\text { and minimised transit traffic }\end{array}$ & $\begin{array}{l}\text { Navigation system for } \\
\text { car drivers; Fleet } \\
\text { management system }\end{array}$ \\
\hline Transport & $\begin{array}{l}\text { The no parking spaces will be set at a low } \\
\text { level for residential/work. }(9.2 .7)\end{array}$ & Reduced land use for parking spaces. & $\begin{array}{l}\text { Traveler information } \\
\text { system }\end{array}$ \\
\hline Transport & $\begin{array}{l}\text { The living/working in the area should be } \\
\text { offered a personalised itinerary } \\
\text { for sustainable travel options and to } \\
\text { minimise their transportation. }(9.2 .10)\end{array}$ & $\mathrm{n} / \mathrm{a}$ & $\begin{array}{l}\text { Traveler information } \\
\text { system }\end{array}$ \\
\hline $\begin{array}{l}\text { Housing/ } \\
\text { Premises }\end{array}$ & $\begin{array}{l}\text { Housing/premises shall contain usually } \\
\text { friendly system for individual } \\
\text { measurement/visualisation/reading/ } \\
\text { control of energy/water/ waste. (10.2.8) }\end{array}$ & $\begin{array}{l}\text { Places and technology for metering and visualisation } \\
\text { in buildings for residential or commercial use. }\end{array}$ & $\begin{array}{l}\text { Advanced metering } \\
\text { for energy, water, } \\
\text { waste }\end{array}$ \\
\hline $\begin{array}{l}\text { Housing/ } \\
\text { Premises }\end{array}$ & $\begin{array}{l}\text { Advanced ICT with high performance } \\
\text { should be installed in buildings to provide } \\
\text { services to residents and businesses in area. } \\
(10.2 .9)\end{array}$ & Fiber in residential and commercial buildings. & $\begin{array}{l}\text { General ICT } \\
\text { infrastructure }\end{array}$ \\
\hline
\end{tabular}

